\title{
Trivial Name Data Type
}

National Cancer Institute

\section{Source}

National Cancer Institute. Trivial Name Data Type. NCI Thesaurus. Code C95696.

A data type comprised of the words or language units by which an entity is known. 